\title{
Environmental Factors Influence Toward The Establishment Of Business: A Survey In Jabodetabek
}

\author{
${ }^{1}$ Kevin Keanu Muhammad, ${ }^{2}$ Muhammad Faiq Gibraltar, ${ }^{3}$ Ricky Septiawan \\ ${ }^{1} J l$ Dahlia 1, no: 46, Komplek Pakuan 2. Bogor, Jawa Barat, Indonesia \\ ${ }^{2} J l$ Kapten Naseh, no: 38, Tasikmalaya, JawaBarat, Indonesia \\ ${ }^{3}$ Jl. Kemang Timur XI, No: 10, Jakarta Selatan, Jawa Barat, Indonesia
}

\begin{abstract}
Research Methodology is one way to do a research to find the answer of the specific question or statement. In this research methodology we will try to prove whether environmental factor have influence in someone to establish a business. We addressed this research to from student and above in Jabodetabek. We use questionnaire to gather information from our respondent. The result of the questionnaire will be analyze so that we can get to know whether environment have influence or not and what is the effect towards the respondent point of view of the business. The conclusion of the research is that environmental factor has influence in someone to establish a business.
\end{abstract}

Keywords: environmental factor, family factor, education factor, peers factor, business, passion

\section{Introduction}

Human is social being. We can't live without socializing with other, therefor realizing or not environment has a big influence in someone's life. Starting from family where we spent our life with, our peer group that grew with us together, to study environment. Oxford dictionary said "(the environment) the natural world, as a whole or in a particular geographical area, especially as affected by human activity". Environment in other word dfinition of environment consist of condition and the realm with its way influence our behavior, growth, and life proceses (Hartoto,2008).

Environmental factors are very influential in people's lives where the environment can determine how the human future will be. In building a business, environment has a very important role as business can be formed by our surroundings condition. Environment affect the human mind. Environmental factors in the formation of a business is divided into several factors, the first is the family environment, friends and the school environment . Family environment affects the percentage of a person's tendencyof business, where the family has a high level mindset. Family factormakes a person familiar with the business world because it has a family background that already have a business ( Leon., 2007 ). Someone who comes from a family with a background of business will observe the process of entrepreneurial from the father and the mother. This will make the people more interested in the work that has high level of flexibility and independence ( Brockhause, Hisrich , \& Brush, Leon et al ., 2007). Surrounding environment can affect the formation of the business, where the friend or the people around have knowledge of the business or act as businessmen, it will trigger someone's mind to open a business. Social support will give someone hope and confidence that he will have the support to start a new business of a close relative " group belonging " such as parents, siblings and their partners and from the " reference " group such as friend, colleague and lecturer ( leon et al ., 2007). The role of the school, university or other educational aspect contribute in building a business, because with a good education program will develop one's thinking power. The role of education continues to evolve toward the formation of entrepreneurs with entrepreneurial programs that can stimulate business formation . Entrepreneurship education related to a set of educational and training programs that try to change the behavior of entrepreneurial or provide elements that affect a person's intentions such as knowledge entrepreneurship , foster entrepreneurship desires through entrepreneurial activity ( Linan, Selcuk \& Turker , 2009). The purpose of this research is to discover how environment can influence people to establish a business, this research has two specific reseach such as:

1. Does environment give impact to the motivation of people to establish business?

2. Does environment give influence towards the development economic of Indonesia particularly in development SMEs?

This research has three parts. The first part reviews the relevant literature used to this research and the research problem. Then it is followed by the validity and realibility test of the data collected that suitable with the research queston. Finally, the last part will presents about the result from this research. 


\section{Literature Review}

Environment are the surrounding that people or creatures live in, said by www.oxforddictionaries.com . We live in our environment, from our closest person which is our family, to the people that comes to study with us in school or university, that is our environment. We cannot live without the people around us because human nature is social being. Since the beginning, our closest environment, which is family, teach us to act and to live in this world. Our family teach us to eat, to think, to react to everyday activity. This leads to conclusion that or environment affect the way that we think. Our closest companion besides family are our friends, which we spent and share our thought and feelings. "Children and adults alike are influenced by their peers, but children who are still in the process of developing a value system are more vulnerable to negative influences" said by Dr. Silvya Rimm 2010. We can say that peers have an influence to our life. If we spend our time with business people, or student who have a business we will likely be more open to establishing a business.

Another big factor that will affect our likelyhood to established a business is education. Ivana Bilic, Ante Prka, and Gaia Vidovic (2011) mention in their writing about the influence of education to entrepreneurship orientation that entrepreneur education will help entrepreneurial activity by changing mindset and providing people with necessary skills. By knowing the theory and skills it help us to establish business because we can identify, analize and then start one.

There are any several factor beside education, there is family and passion. The factor influence people to start their business, especially in our research are people who take business faculty or entrepreneurship program. This factor can influence the mind set to start up business. The family factor, in the psychological side from entrepreneur, family is one of the key factors to get a successful entrepreneur said by Llwellyn and Wilson (2003). When we have family members as entrepreneur we can learn and get more knowledge directly to expand our entrepreneur soul. This will be an influence to start up the business and increase the experience.

Passion, passion is important key in entrepreneur, it will use to form strong mentality and growth, and it is influencing the entrepreneurial activities stated by Shane et al (2003). When we do the business with our passion it will make us enjoy doing that and it will make easier. Environment could affect someones action to everday activities (J. Gordon, 2009). There are several factors of environment that contribute

Business have three different sizes, there are micro-enterprise, small medium enterprise and large enterprise. According to government policy number 20 year 2008 about small medium enterprise or in bahasa usaha mikro, kecil menengah (UMKM), micro enterprise are a productive effort owned by a person that fulfill the criteria of micro business. The total asset of a micro business is maximum Rp 50.000 .000 while the maximum profit is Rp. 300.000 .000

Small medium enterprises have some definition. According to ec.europa.eu small medium enterprise are companies that have employees under certain limits. The abbreviation "SMEs" is use by international organization such as the UN, WTO and World Bank. They also have another factor to determine whether a company is a SMEs which is the turn over or balance sheet total. The small enterprise has to have fewer than $50 \%$ employees, under or equal 10 million euro turn over or 10 million euro balance sheet total. For the medium enterprise the number of employees has to be below 250 people. The number of turnover has to be under or below 50 million euro or 43 million euro balance sheet total. Another definition came from Bolton Committee in its 1971 report on small firms.it stated that small firm is an independent business, manage by the owner or part-owner and having a small market share. The Bolton report have a statistical definition like this a turnover of not more than 2.8 million pounds, balance sheet total not more than 1.4 million pounds and not more than 50 million employees. For medium size enterprise, the turnover not more than 11.2 million pounds and the balance sheet total not more than 5.6 million pounds, the number of employees not more than 250." Small business can vary widely from simple forms as of self-employment, such as the digging gardens, erecting fences, running a post office, or corner shop, to the management of a high technology company on a scale which, relative to others in a particular sector, is small" said Sexton and Bowman.

In Indonesia SMEs have different definition and role. SMEs or Usaha Kecil Menengah (UKM) in bahasa is term leading to a small business which has wealth Rp 50.000.000 until maximum Rp500.000.000 not include the assets has been stated in policy No 20/2008. The importance of SMEs is that SMEs can prove to support economy condition of Indonesia. This situation happen because the big business is more likely to collapse and cause stir in the nation economic, it is the role of SMEs to stabilize it. We can say that because the percentage of growth SMEs in Indonesia. In 2005the number of SMEs is 47.1 million from $99 \%$ of business in Indonesia and in 2006 the number of SMEs is growing to be 48.9 million units. In this case it will make much job vacancy for people in Indonesia. In 2005 be found 83.2 workers from SMEs and growing will be 85.4 workers in 2006. In this case SMEs show SMEs will be community empowerment and support economy condition in Indonesia. "I'm very proud of the growth SMEs Indonesia. The growth of SMEs Indonesia already achieved to 55.2 million in Indonesia," stated by minister of corporation and SMEs SyarifHasan (2013). 


\section{Methodology}

The sampling frame is a list of environmental factor that have influence to people who consider to establish business. The stratified sampling which will be use is a method of sampling. It is a process of dividing members of population into a typical smaller group. Hughton Mifflin (2010) said that stratified sampling is a sampling procedure in which a population is separated into subgroups (strata) and then samples are selected from each subgroup, stratified random sampling is used when homogeneous subgroups can be identified within a heterogeneous population. The disadvantages of this method are it is a rather more complex method to use, we need to determine the strata right before we can receive our useful feedback. More effort needs to be done in order to get the sampling from the subgroup that have been determined as the subgroup may be a little group or people that are a bit difficult to find.

This research is addressed to our respondent in Jabodetabek. We will conduct the survey to minimal 200 respondents to get the best result. From the number that we get from the sampling we will find out how many people consider to establish business, people who are affected by environmental factor. We have 217 respondent in our survey. Base on the result we have $117(53 \%)$ male respondents and $100(47 \%)$ female respondents. We classified the respondents into four different classes which are student, employee, entrepreneur, and others (housewife, labour, etc). From the result we have 133 (61\%) student, 27 (12\%) employee, 40 (19\%) entrepreneur, and $17(8 \%)$ others. We also gather information about the age, we classified the age into four categories there are 15 - 20 years old, 21 - 25 years old, 26 - 30 years old, and above 30 years old, and the result is $15-20$ years old is $114(53 \%)$ respondent, $21-25$ years old is 39 (18\%), $26-30$ is 35 $(16 \%)$, and above 30 years old is $29(13 \%)$. From the data that we received we will analyze the impact and influence of environmental factor to the establishment of business in Jabodetabek.

Data of the questionnaire were well manage and consist of 20 questions with four main variables. Those variables are environment and business, education, the thing should have to do in business, and interested and desire to open business. The questions were uploaded beforehand and were distributed using personal approach and online instrument (google drive, BBM, Line, whatsapp, facebook). After two weeks of distribution, we only have 16 valid questions based on the SPSS program.

The questionnaire have five types of answer, there are [1 (strongly disagree), 2 (disagree), 3 (neutral), 4 (agree), 5 (strongly agree)], these five types of answer is a measurement of how agree or disagree the answer is. Quantitative analysis were used to analyze the tabulated data. To analyze the validity data we use factor analysis, factor analysis is a statistic procedure with the function of finding a number of factors used to represent the relation between dependent and independent variable. In our research we will use this factor analysis to find numbers that will be the representative of the correlation between environmental factor and number of people desired to open business. And to analyze reliability we use cronbach's alpha, cronbach's alpha is a way to measure internal consistency of how close the relations of asset of items as a group, this method use to focus on one variable. IBM SPSS 20.0 statistical processing software were used to analyze and process the data.

\section{Data Analysis, Presentation, And Result}

KMO and Bartlett's Test

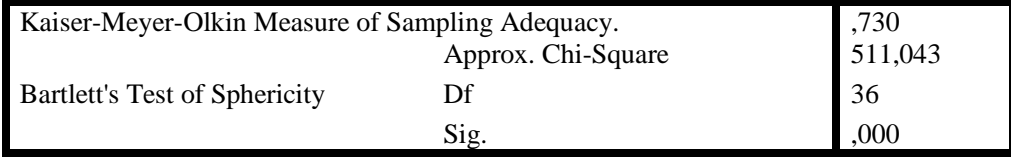

The table above shows the KMO and Bartlett's Test. KMO shows the correlation between the statements. The result of KMO should bigger and not less than 0.5 (Jones, n.d).We have to have KMO greater than 0.5 to have a valid data, here we can see that we have 0.730 which is greater than 0.5 , so our data is valid. The significance, in the other hand, should be below 0.05 which in this case we have 0.000 . The KMO will be not valid if it is below 0.5 . We can change the number of KMO by deleting samples.

Communalities
\begin{tabular}{|l|l|l|}
\hline & Initial & Extraction \\
\hline EB1 & 1,000 &, 687 \\
EB2 & 1,000 &, 711 \\
EB3 & 1,000 &, 682 \\
EB5 & 1,000 &, 560 \\
E1 & 1,000 &, 837 \\
E4 & 1,000 &, 844 \\
TSB1 & 1,000 &, 734 \\
TSB2 & 1,000 &, 745 \\
TSB3 & 1,000 &, 748 \\
\hline
\end{tabular}

Extraction Method: Principal Component Analysis. 
The table above show the communalities result. The extraction value should be greater than 0.5 in each variable, because total of respondents is 215 respondents. All of value are greater than 0.5 Field, A.P. (2005) chapter 15.Usually the communalities are above 0.5 , here in our data we have all above 0.5 for the nine of it. All the data are valid base on the instruction because all of the data we have are above 0.5. EB5 are barely made it above 0.5 but still, it is valid. We use principal extraction method for this table.

Total Variance Explained

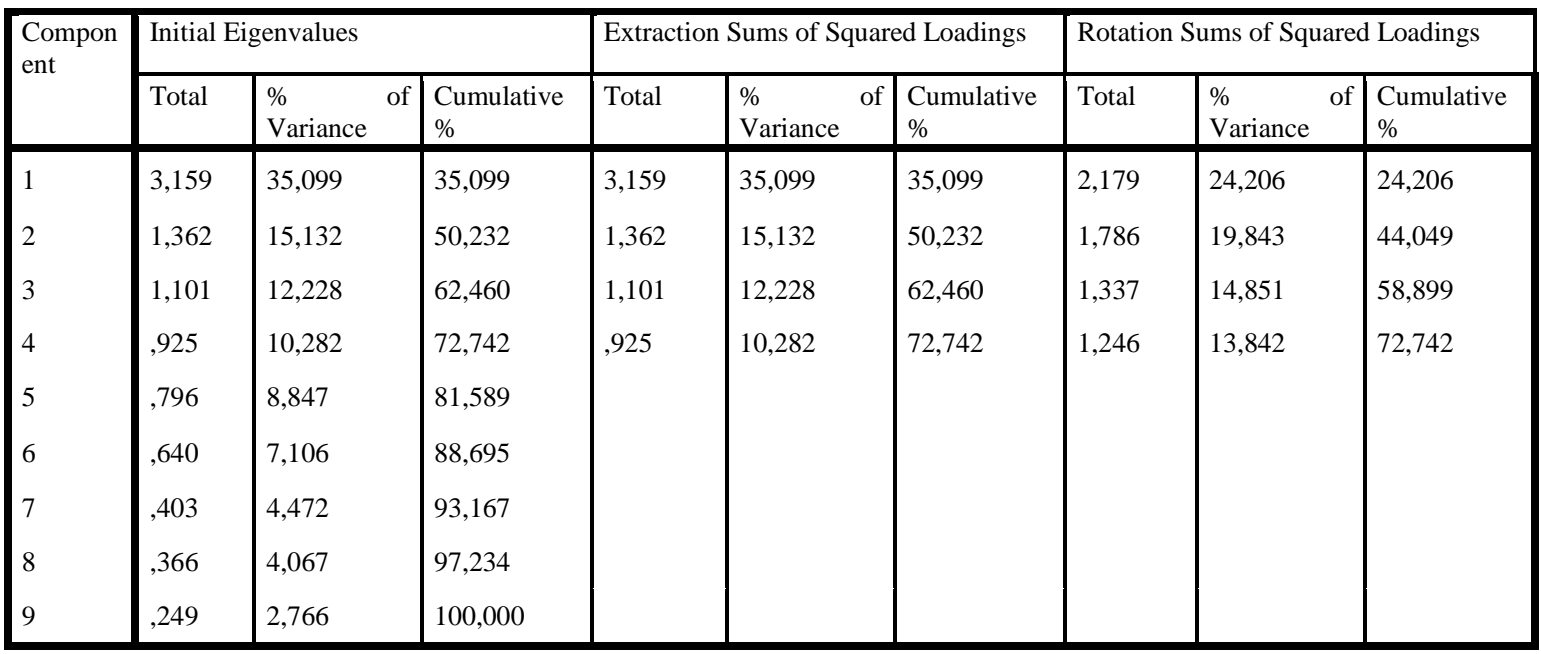

Extraction Method: Principal Component Analysis.

The extraction sums of squared loadings total's number should be above 0.5. Our data shows that we have extraction sums of squared loadings total above 0.5 , so we can say that our data is valid. In case the grades are below 0.5, we can use the solution of deleting some sample to increase the number of extraction grade. All the variance is valid data and all the variable can be determine without an error data (Institute for Digital Research and Education, 2013).

Rotated Component Matrix

\begin{tabular}{|c|c|c|c|c|}
\hline & \multicolumn{4}{|c|}{ Component } \\
\hline & 1 & 2 & 3 & 4 \\
\hline $\begin{array}{l}\text { TSB1 } \\
\text { TSB2 } \\
\text { TSB3 } \\
\text { E1 } \\
\text { E4 } \\
\text { EB2 } \\
\text { EB1 } \\
\text { EB3 } \\
\text { EB5 }\end{array}$ & $\begin{array}{l}, 839 \\
, 835 \\
, 785\end{array}$ & $\begin{array}{l}, 887 \\
, 886\end{array}$ & $\begin{array}{l}, 807 \\
, 776\end{array}$ & $\begin{array}{l}, 780 \\
, 684\end{array}$ \\
\hline
\end{tabular}

Extraction Method: Principal Component Analysis.

Rotation Method: Varimax with Kaiser Normalization.

a. Rotation converged in 6 iterations.

This data we have is valid because we have only one each for the data number. TSB1, TSB2, TSB3 have each fill one component. E1 and E4 fill one component. EB2 and EB1 fill one component which is component 3. EB3 and EB5 also fill one component which is component 4. The data should only fill one component each. If the data fill not only one but two component, then it the data are not valid. For example, if TSB 1 filling the component 1 and component 2 then we can say that the data are not valid.

It means that factor analysis in each variable in the contents is valid Field, A.P. (2005) chapter 15. 
Dependent variable

Total Variance Explained

\begin{tabular}{|l|l|l|l|l|l|l|}
\hline \multirow{2}{*}{ Component } & \multicolumn{2}{l|}{ Initial Eigenvalues } & \multicolumn{3}{l|}{ Extraction Sums of Squared Loadings } \\
\cline { 2 - 7 } & Total & $\%$ of Variance & Cumulative \% & Total & \% of Variance & Cumulative \% \\
\hline 1 & 4,307 & 53,832 & 53,832 & 4,307 & 53,832 & 53,832 \\
2 &, 923 & 11,533 & 65,365 & & & \\
3 &, 727 & 9,082 & 74,448 & & & \\
4 &, 619 & 7,733 & 82,181 & & & \\
5 &, 480 & 6,005 & 88,186 & & & \\
6 &, 460 & 5,752 & 93,938 & & & \\
7 &, 295 & 3,683 & 97,621 & & & \\
8 &, 190 & 2,379 & 100,000 & & & \\
\hline
\end{tabular}

Extraction Method: Principal Component Analysis.

\section{ANOVA $^{\mathrm{a}}$}

\begin{tabular}{|ll|l|l|l|l|l|}
\hline Model & Sum of Squares & df & Mean Square & F & Sig. \\
\hline \multirow{3}{*}{1} & Regression & 66,699 & 3 & 22,233 & 77,852 &, $000^{\mathrm{b}}$ \\
& Residual & 60,257 & 211 &, 286 & & \\
& Total & 126,956 & 214 & & & \\
\end{tabular}

a. Dependent Variable: AVRG4

b. Predictors: (Constant), AVRG3, AVRG1, AVRG2

ANOVA or analysis of variance used to compare means of three or more variables. It provides statistical test to tell whether the means are equal or not. For ANOVA, we have to have the significance not more than 0.05 . We have 0.000 significance number which is valid based on the instruction.

\section{Coefficients $^{\mathrm{a}}$}

\begin{tabular}{|c|c|c|c|c|c|c|c|c|c|c|}
\hline \multirow[t]{2}{*}{ Model } & \multicolumn{2}{|c|}{$\begin{array}{l}\text { Unstandardized } \\
\text { Coefficients }\end{array}$} & \multirow{2}{*}{$\begin{array}{l}\text { Standardized } \\
\text { Coefficients }\end{array}$} & \multirow[t]{2}{*}{$\mathrm{T}$} & \multirow[t]{2}{*}{ Sig. } & \multicolumn{3}{|c|}{ Correlations } & \multicolumn{2}{|c|}{$\begin{array}{l}\text { Collinearity } \\
\text { Statistics }\end{array}$} \\
\hline & B & Std. Error & & & & $\begin{array}{l}\text { Zero- } \\
\text { order }\end{array}$ & Partial & Part & Tolerance & VIF \\
\hline (Constant) &, 870 &, 211 & & 4,118 & ,000 & & & & & \\
\hline 1 AVRG1 & ,464 & ,060 & ,439 & 7,802 & , 000 & ,646 & , 473 &, 370 &, 711 & 1,407 \\
\hline AVRG2 &, 194 &, 053 & ,205 & 3,637 & ,000 &, 523 & 243 &, 172 &, 711 & 1,407 \\
\hline AVRG3 & 177 & ,038 &, 253 & 4,601 & ,000 & .533 & ,302 &, 218 &, 743 & 1,346 \\
\hline
\end{tabular}

a. Dependent Variable: AVRG4

Here we have coefficient table. The $\mathrm{T}$ test significance needs to be under 0.05 . All of our significance has 0.000 which is valid for all the data.

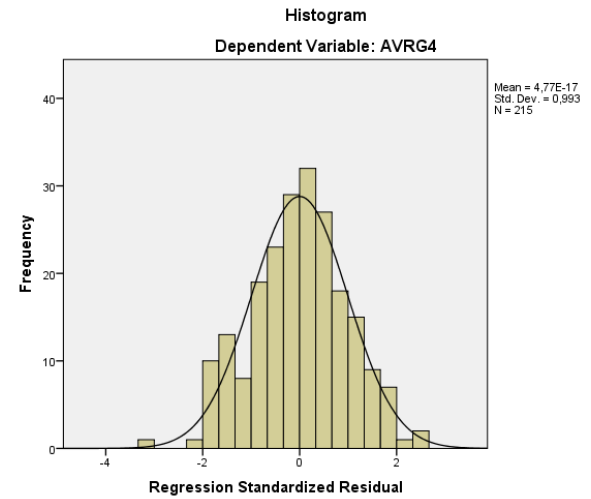

Here in our histogram, we have the guideline for the graph to be considered valid or not. The data are considered valid when most of the bars are inside the guideline. This is a good data that we have because most of the bars are inside the guideline. The shape of the bars also forming the A shape of the guideline where the line is having a peak point in $\mathrm{x} 0$. 


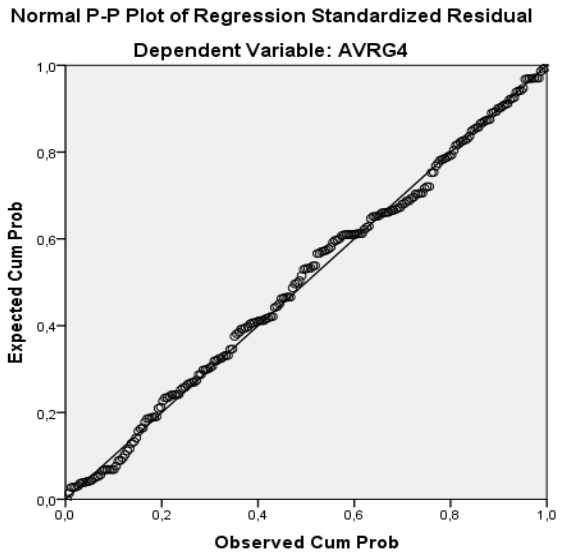

For this graph, we have the guideline rising from the bottom left to the top right. The data will be valid if the circles follow the guideline. We can see that the circle are distribute along the guideline which makes our data valid.

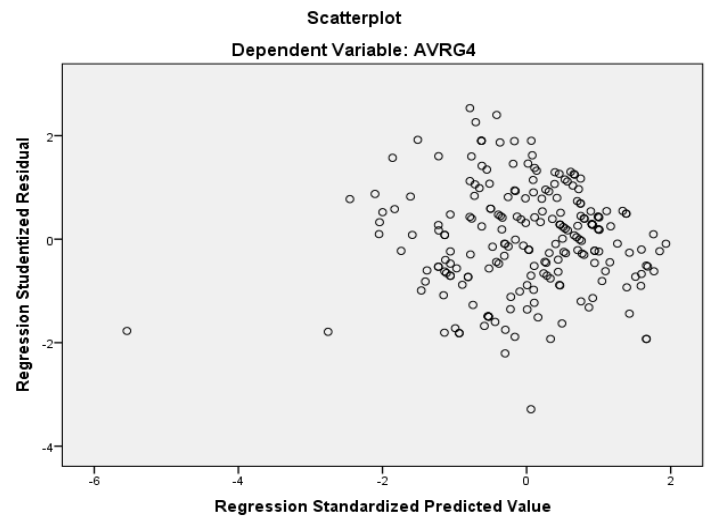

For the scatterplot to be valid, we have to have the circles distribute equally under and above the zero point. In our graph the circles are scattered nice and equally below and above the zero point. This scattering of the circles determined that the data we have is valid.

\begin{tabular}{|c|c|c|c|c|c|c|c|c|c|c|}
\hline \multicolumn{11}{|c|}{ Model Summary $^{\mathbf{b}}$} \\
\hline \multirow{2}{*}{$\begin{array}{l}\text { Mod } \\
\text { el }\end{array}$} & \multirow[t]{2}{*}{$\mathrm{R}$} & \multirow{2}{*}{$\begin{array}{l}\mathrm{R} \\
\text { Square }\end{array}$} & \multirow{2}{*}{$\begin{array}{l}\text { Adjusted R } \\
\text { Square }\end{array}$} & \multirow{2}{*}{$\begin{array}{l}\text { Std. Error } \\
\text { of the } \\
\text { Estimate }\end{array}$} & \multicolumn{5}{|c|}{ Change Statistics } & \multirow{2}{*}{$\begin{array}{l}\text { Durbin- } \\
\text { Watson }\end{array}$} \\
\hline & & & & & $\begin{array}{l}\mathrm{R} \text { Square } \\
\text { Change }\end{array}$ & \begin{tabular}{|l|}
$\mathrm{F}$ \\
Change
\end{tabular} & df1 & df2 & $\begin{array}{|ll|}\begin{array}{l}\text { Sig. } \\
\text { Change }\end{array} & \text { F } \\
\end{array}$ & \\
\hline 1 &, $725^{\mathrm{a}}$ &, 525 &, 519 &, 53440 &, 525 & 77,852 & 3 & 211 &, 000 & 1,543 \\
\hline
\end{tabular}

a. Predictors: (Constant), AVRG3, AVRG1, AVRG2

b. Dependent Variable: AVRG4

This is the summary of the data we have. We can see the number which we have in the previous table summarized here.

\section{Discussion and conclusion}

This research found that environmental factors have influence towards the establishment of business. The environmental factors, which help in developing the mindset of someone, will make someone react to the surrounding based on their judgment and experience develop by their environment. If someone encounter a lot of business activity in their life they will see everything based on the business perspective. Skill and experience also contribute a big influence in this case. For instance if someone was born in a business family they will likely to establish a business because they have the mindset of business and they have experience a lot of business activity in their family activity. Education also have a role as someone more likely to establish a business if they have the skill and knowledge of business. More business school should be establish in order to increase the number of entrepreneur or business because business, especially the SME, are a country economic foundation. 
More research should be conducted in order to know the factor of the establishment of business. It is better to have the research of the business success factor based on the field of operation and location. By doing so and implement it we can help to create the economic foundation of Indonesia

Environmental factors indeed have an influence towards the establishment of business. In this research we can find the evidence of how environmental factors could influence the establishment of business. It is very important to know the factors of business establishment because business are the country's economic foundation.

\section{Acknowledgement}

In the name of Allah most gracious, most merciful research.

First of all, we are willing to present our grateful to Allah SWT for establishing us to complete this

We wish to express my sincere thanks to our parents and our family who always support and pray for us to complete this research.

We are willing to present our thanks to everyone who has helped us to complete this research.

We also thank to our advisor, Mr. Suresh Kumar, lecturer, Department of Business Administration for his valuable guidance, encouragement, advice and suggestion which are help us to finish our research methodology. We are extremely grateful and indebted to him for his expert, sincere and valuable guidance and encouragement extended to us.

\section{Preferences}

[1] Rimm, Sylvia. (2010). Peer Influence. Retrived from http://www.sylviarimm.com/article peerinf.html

[2] Evan, Brandons. (2012). Be Held The Power of Peer Influence: 5 Keys to Succeshttp://socialmediatoday.com/bencrowdtap/549666/behold-power-peer-influence-5-keys-success-influencer-marketing Chen, Y. a. (2006). Testing The Entrepreneurial Intention Model On a Two Country Sample. Document de tereball, 1-28.

[4] Ghozzali, I. (2007). Aplikasi Analisis Multivariate dengan Program SPSS. Semarang : Badan Penerbit Universitas Dipenogoro.

[5] lian, A. (2004). The University Environment and Academic Entrepreneurship : A Behavioral Model for Measuring Environment Succes. How School of Technology Management, 1-25.

[6] Selcuk, S. a. (2009). Which Factors Affect Entrepreneurial Intention of University Students. Journal of European Industrial Training , 3(2), 142-159.

[7] Field, A.P. (2005). Discovering statistics using SPSS (2 $2^{\text {nd }}$ edition). London: Sage. Retrieved from http://www.statisticshell.com/docs/factor.pdf

[8] Institute for Digital Research and Education. (2013). Annotated SPSS Output Principal Components Analysis. Retrieved from http://www.ats.ucla.edu/stat/spss/output/principalcomponents.htm

[9] Jones and Bartlett Publishers. (n.d). Factor Analysis Path Analysis, and Structural Equation Modeling. Retrieved from http://www.jblearning.com/samples/0763755486/55485 CH14 Walker.pdf

[10] Dyah Ayu Widi Astuti surakarta (2009) PENGARUH KONTEKS KELUARGA, KERJA, PENDIDIKAN, HAMBATAN DALAM MEMULAI BISNIS, DUKUNGAN SOSIAL, NILAI - NILAIINDIVIDUALISME DAN KOLEKTIVISMEPADA INTENSI

BERWIRAUSAHA fakultas ekonomi sebelas maret surakarta

[11] http://blog.vistage.com/business-leadership/peers-and-the-power-of-persuasion/

[12] http://www.depkop.go.id/index.php?option=com_content\&view=article\&id=129

[13] shane. (2003). the nature of emotions in entrepreneurship. entrpreneurial passion, 1.

[14] Hasan, S. (2013). UMKM serap 97 Persen Tenaga Kerja di Indonesia. Kementerian Koperasi dan Usaha Kecil dan Menengah Republik Indonesia.

1. Appendix

Questioner About Environmental Factor Toward The Estabilishment Of Business: A Survey In Jabodetabek

Questioner

Environment and Business

1.Having an entrepreneur family member will give impact to your will to establishing business

$\begin{array}{lllll}1 & 2 & 3 & 4 & 5\end{array}$

Strongly Disagree

Select a value from a range of 1, Strongly Disagree, to 5,Strongly Agree,.

Strongly

Agree

2. Having an entrepreneur friends will give impact to your will to establishing business

$\begin{array}{lllll}1 & 2 & 3 & 4 & 5\end{array}$

Strongly Disagree

Select a value from a range of 1, Strongly Disagree, to 5,Strongly Agree,.

3. I make sure that I know the latest developments in the fields of my hobbies 


$\begin{array}{lllll}1 & 2 & 3 & 4 & 5\end{array}$

Strongly Disagree

Select a value from a range of 1,Strongly Disagree, to

5,Strongly Agree,.

4. You feel your peers, environment, school and family affect your will to establish a business

$$
\begin{array}{lllll}
1 & 2 & 3 & 4 & 5
\end{array}
$$

Strongly Disagree

Select a value from a range of 1, Strongly Disagree, to 5,Strongly Agree,.

Strongly

Agree

5. The quality of your University, environment, friend and family will affect to your business future

$$
\begin{array}{lllll}
1 & 2 & 3 & 4 & 5
\end{array}
$$

Strongly Disagree

Select a value from a range of 1,Strongly Disagree, to 5,Strongly Agree,.

\section{Education}

6. Have knowledge about entrepreneurship

$\begin{array}{lllll}1 & 2 & 3 & 4 & 5\end{array}$

Strongly Disagree

Select a value from a range of 1,Strongly Disagree, to 5,Strongly Agree,.

\section{Venture creation before graduation}

$\begin{array}{lllll}1 & 2 & 3 & 4 & 5\end{array}$

Strongly Disagree

Select a value from a range of 1,Strongly Disagree, to 5,Strongly Agree,.

8. Effectiveness of entrepreneurship importance of education on venture creation

$$
\begin{array}{lllll}
1 & 2 & 3 & 4 & 5
\end{array}
$$

Strongly Disagree

Select a value from a range of 1, Strongly Disagree, to

5,Strongly Agree,.

9. Has the pupil received entrepreneurship training

$$
\begin{array}{lllll}
1 & 2 & 3 & 4 & 5
\end{array}
$$

Strongly Disagree

Select a value from a range of 1,Strongly Disagree, to

5,Strongly Agree,.

\section{The things should have to do in business}

10. You have explore whether there is a market or demand for your idea

$$
\begin{array}{lllll}
1 & 2 & 3 & 4 & 5
\end{array}
$$

Strongly Disagree

Select a value from a range of 1,Strongly Disagree, to 5,Strongly Agree,. 


$\begin{array}{lllll}1 & 2 & 3 & 4 & 5\end{array}$

Strongly Disagree

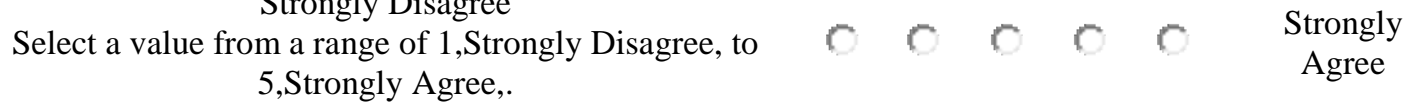

12. You have manage your money to develop your business

$\begin{array}{lllll}1 & 2 & 3 & 4 & 5\end{array}$

Strongly Disagree

Select a value from a range of 1,Strongly Disagree, to

5,Strongly Agree,.

\section{Interest and desire to open a business}

13. You have made a business plan

$$
\begin{array}{lllll}
1 & 2 & 3 & 4 & 5
\end{array}
$$

Strongly Disagree

Select a value from a range of 1,Strongly Disagree, to 5,Strongly Agree,.

Strongly

Agree

14. You think about being an entrepreneur

$$
\begin{array}{lllll}
1 & 2 & 3 & 4 & 5
\end{array}
$$

Strongly Disagree

Select a value from a range of 1,Strongly Disagree, to 5,Strongly Agree,.

\section{\begin{tabular}{l|l|l|l|l}
$C$ & 0 & 0 & $\begin{array}{c}\text { Strongly } \\
\text { Agree }\end{array}$
\end{tabular}}

15. Strongly consider setting up my own business

$$
\begin{array}{lllll}
1 & 2 & 3 & 4 & 5
\end{array}
$$

Strongly Disagree

Select a value from a range of 1,Strongly Disagree, to 5,Strongly Agree,.

16. Am willing to work hard to set up my own business

$$
\begin{array}{lllll}
1 & 2 & 3 & 4 & 5
\end{array}
$$

Strongly Disagree

Select a value from a range of 1,Strongly Disagree, to
5,Strongly Agree,.

17. You would take a course or training program that focuses on entrepreneurship

$$
\begin{array}{lllll}
1 & 2 & 3 & 4 & 5
\end{array}
$$

Strongly Disagree

Select a value from a range of 1, Strongly Disagree, to

5,Strongly Agree,.

18. If you have opportunity to establish a business you will use it

$$
\begin{array}{lllll}
1 & 2 & 3 & 4 & 5
\end{array}
$$

Strongly Disagree

Select a value from a range of 1, Strongly Disagree, to

5,Strongly Agree,.

19. Having a business will help you establish a new one

$$
\begin{array}{lllll}
1 & 2 & 3 & 4 & 5
\end{array}
$$


Strongly Disagree

Select a value from a range of 1,Strongly Disagree, to $6|C| r|C| C \mid$ Strongly

5,Strongly Agree,

Agree

20. Young people are entreprising

$\begin{array}{lllll}1 & 2 & 3 & 4 & 5\end{array}$

Strongly Disagree

Select a value from a range of 1,Strongly Disagree, to

5,Strongly Agree,.

Agree 